\title{
COMPARISON OF TRAVEL-TIME APPROXIMATIONS FOR UNCONVENTIONAL RESERVOIRS FROM SANTOS BASIN, BRAZIL
}

\author{
Nelson Ricardo Coelho Flores Zuniga, Eder Cassola Molina and Renato Luiz Prado
}

\begin{abstract}
The reflection seismic method is extremely important for the hydrocarbon exploration. With more complex geological structures, as the pre-salt from Santos Basin, the reservoir exploration becomes more challenging and the multicomponent seismic investigation improves its mapping and characterization. To obtain multicomponent seismic data of an offshore survey it is necessary to use the OBN (Ocean Bottom Nodes) technology. The converted wave behavior, the large offsets and the difference of datum between source and receptors for layered media, results in strong nonhyperbolic travel-time events. Furthermore, the complexity and peculiarities of some unconventional reservoirs found in the pre-salt also increase the difficulty to perform the velocity analysis. For these reasons, it is necessary to use nonhyperbolic multiparametric travel-time approximations to control the nonhyperbolicity. Here we perform the comparison of nonhyperbolic travel-time approximations of seismic reflection events derived from geological models. The numerical study was considered as an inverse problem and it was treated according to an optimization criterion. The complexity analysis was performed in order to understand the behavior of each approximation concerning the unicity. After the computation of the relative errors between the observed curve and the calculated curve for each nonhyperbolic approximation, it was possible to find out the one with the highest accuracy for the events tested here.
\end{abstract}

Keywords: multicomponent, OBN, nonhyperbolic.

RESUMO. 0 método sísmico de reflexão é extremamente importante para a exploração de hidrocarbonetos. Com estruturas geológicas mais complexas, como o présal da Bacia de Santos, a exploração de reservatórios se torna mais desafiadora e a utilização da sísmica multicomponente promove o mapeamento e a caracterização estrutural. Para obter-se dados de sísmica multicomponente em um levantamento offshore é necessário utilizar a tecnologia OBN (Ocean Bottom Nodes). 0 comportamento de ondas convertidas, Iongos afastamentos e diferença de datum entre fonte e receptores para meios estratificados resultam em uma forte não-hiperbolicidade dos eventos de tempos de trânsito. Além disso, a complexidade e peculiaridades, de alguns reservatórios não convencionais encontrados no pré-sal, também aumentam a dificuldade em realizar a análise de velocidades. Por estes motivos, é necessário usar aproximações não-hiperbólicas multiparamétricas de tempos de trânsito para controlar os efeitos da não-hiperbolicidade. No presente trabalho, foi realizada a comparação de aproximações não-hiperbólicas de tempos de trânsito de eventos sísmicos de reflexão provenientes de modelos geológicos. 0 estudo numérico foi considerado como um problema inverso e foi tratado de acordo com um critério de otimização. A análise de complexidade foi realizada para compreender o comportamento de cada aproximação com respeito a unicidade. Após computar os erros relativos entre a curva observada e as calculadas com cada aproximação, foi possível descobrir a aproximação que apresentou maior precisão para os testes realizados.

Palavras-chave: multicomponente, OBN, não-hiperbólicas.

Universidade de São Paulo (IAG-USP), Departamento de Geofísica, Instituto de Astronomia, Geofísica e Ciências Atmostéricas. Rua do Matão 1226, $05508-090$ Cidade Universitária, São Paulo, SP, Brazil. Phone: +55(11) 3091-4755; Fax: +55(11) 3091-5034 - E-mails: nelson.zuniga@iag.usp.br; eder.molina@iag.usp.br; renato.prado@iag.usp.br 


\section{INTRODUCTION}

The velocity analysis of the multicomponent seismic data from OBN (Ocean Bottom Nodes) acquisition is a challenge for offshore exploration. The travel-time approximations play an important role in the reflection seismic processing to perform the velocity analysis (Yilmaz, 2000) once the hyperbolic approach (Dix, 1955) is not valid for converted PS-wave events, for conditions with difference of datum and large offsets between source and receptor, and for layered media. The offshore models of the pre-salt from Santos Basin have some particular characteristics as they are originated from turbiditic depositional system. However, reservoirs with unconventional structural characteristics are found, what makes the seismic processing more complex. To overcome the difficulty of processing the multicomponent seismic data for these kinds of models, it is necessary to use nonhyperbolic multiparametric travel-time approximations (Malovichko, 1978; Li \& Yuan, 2001; Ursin \& Stovas, 2006; Blias, 2009).

Several studies were proposed to understand the nonhyperbolicity from different effects in last decades (Malovichko, 1978; Blias, 1983, 2009; Muir \& Dellinger, 1985; Castle, 1988, 1994; Slotboom, 1990; Tsvankin \& Thomsen, 1994; Alkhalifah \& Tsvankin, 1995; Li \& Yuan, 1999, 2001; Cheret et al., 2000; Causse et al., 2000; Tsvankin \& Grechka, 2000a,b; Fomel \& Grechka, 2000, 2001; Li, 2003; Ursin \& Stovas, 2006; Aleixo \& Schleicher, 2010). Even with a significant number of papers, only few works compare nonhyperbolic approximations in an independent way (Golikov \& Stovas, 2012) and for offshore models using multicomponent seismic data (Zuniga et al., 2015, 2016; Zuniga, 2017).

This paper proposes two stratified offshore models of the presalt from the Santos Basin with unconventional characteristics concerning the geological structure. The travel-time curves studied here are relate to PP and PS reflection events derived from OBN acquisition considering large offsets. To understand the behavior and to recover the aimed parameter, the complexity analysis and the velocity analysis of these events were performed.

\section{TRAVEL-TIME APPROXIMATIONS}

The shifted hyperbola approximation, Eq. (1), was proposed by Malovichko (1978). This approximation was studied and derived by Castle $(1988,1994)$ and de Bazelaire (1988), and was proposed to control the effects in inhomogeneous media using the $S$ parameter.

$$
t=t_{0}^{2}\left(1-\frac{1}{S}\right)+\frac{1}{S} \sqrt{t_{0}^{2}+\frac{S x^{2}}{v^{2}}}
$$

where $x$ is the vector of offsets, $t_{0}$ is the zero-offset travel-time and $v$ is the RMS (Root Mean Square) velocity. The $S$ parameter depends on the $\mu_{4}$ and $\mu_{2}$ by the ratio $S=\mu_{4} / \mu_{2}^{2}$, where $\mu_{j}(j=2,4)$ is the $j$-th velocity momentum, Eq. (2).

$$
\mu_{j}=\sum_{k=1}^{n} t_{k} v_{k}^{j} / \sum_{k=1}^{n} t_{k},
$$

where $v_{k}$ is the interval velocity of the $k$-th layer and $t_{k}$ is the travel-time of the $k$-th layer.

The approximation proposed by Ursin \& Stovas (2006) also uses the $S$ parameter. However, in this case, Eq. (3), the parameter is expressed in a quasi-acoustic case and it is function of the anisotropic parameters of Thomsen (1986).

$$
t=\sqrt{t_{0}^{2}+\frac{x^{2}}{v^{2}}-\frac{(S-1) x^{4}}{4 v^{4}\left(t_{0}^{2}+\frac{(S-1)}{2} \frac{x^{2}}{v^{2}}\right)}}
$$

The Eq. (4), proposed by Blias (2009) is another one which uses the $S$ parameter. For this case the $S$ parameter is related to numerical tests to the walkway vertical seismic profile (VSP).

$$
t=\frac{1}{2} \sqrt{t_{0}^{2}+\frac{1-\sqrt{S-1}}{v^{2}} x^{2}}+\frac{1}{2} \sqrt{t_{0}^{2}+\frac{1+\sqrt{S-1}}{v^{2}} x^{2}}
$$

Different than the other approximations, the Eq. (5), proposed by Li \& Yuan (2001) uses the $\gamma$ parameter to control the nonhyperbolicity. This approximation considers the CP (Conversion Point) to control the effects of the nonhyperbolicity concerning the wave conversion.

$$
t=\sqrt{t_{0}^{2}+\frac{x^{2}}{v^{2}}-\frac{(\gamma-1)}{\gamma v^{2}} \frac{(\gamma-1) x^{4}}{4 t_{0}^{2} v^{2}+(\gamma-1) x^{2}}},
$$

where $\gamma$ is the ratio between the squared P-wave stacking velocity $v_{P 2}$ and the squared converted wave stacking velocity $v_{C 2}$, Eq. (6).

$$
\gamma=\frac{v_{P 2}^{2}}{v_{C 2}^{2}}=\frac{\gamma_{e f f}\left(1+\gamma_{0}\right)}{\left(1+\gamma_{e f f}\right)}
$$

where the relation $\gamma_{\text {eff }}$ is expressed by $\gamma_{e f f}=\gamma_{2}^{2} / \gamma_{0}, \gamma_{2}$ is the ratio between the stacking P-wave and stacking S-wave, and $\gamma_{0}$ is the ratio between P-wave velocity and S-wave velocity which travel along the normal component.

\section{OFFSHORE MODELS STUDIED}

The offshore models studied of the pre-salt are from the Santos Basin, Brazil, based on stratigraphic data from well logs of this region (Fig. 1). The carbonate reservoirs of the two models are sealed by a salt structure. The travel-time curves studied here are 

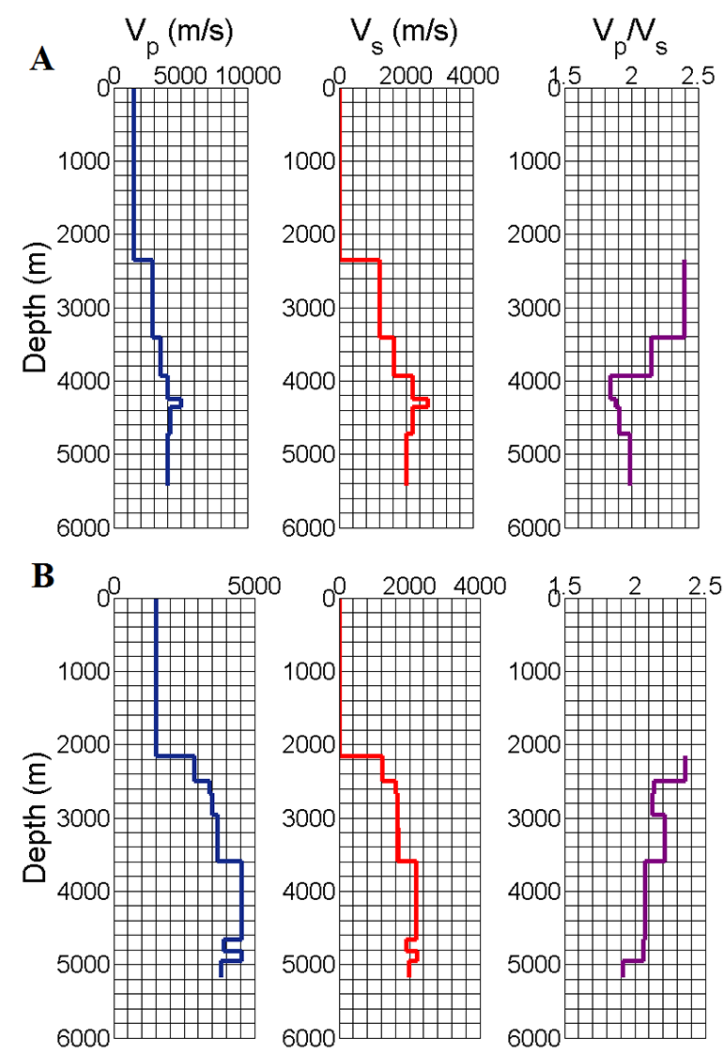

Figure 1 - P-wave velocity $\left(V_{P}\right)$, S-wave velocity $\left(V_{S}\right)$ and $V_{P} / V_{S}$ ratio profiles of the (A) Model 1 and (B) Model 2.

derived from PP and PS events which were reflected in the interface between the top of the reservoir and the base of the salt structure. The maximum offset considered was 15000 meters. The source was on the surface of the ocean and the receptors on the bottom of the ocean (OBN technology).

In Model 1 (Table 1), the 3rd, 4th and 5th layers are part of the salt structure and the carbonate reservoir $\left(V_{P}=4010 \mathrm{~m} / \mathrm{s}\right.$ and $V_{S}=2012 \mathrm{~m} / \mathrm{s}$ ) is beneath this structure which is thinner than the ones usually found.

Table 1 - The parameters of the Model 1: Layer thickness $(\Delta z)$, P-wave velocity $\left(V_{P}\right)$, S-wave velocity $\left(V_{S}\right)$ and $V_{P} / V_{S}$ ratio.

\begin{tabular}{|c|c|c|c|c|}
\hline Layer & $\Delta z(\mathrm{~m})$ & $V_{P}(\mathrm{~m} / \mathrm{s})$ & $V_{S}(\mathrm{~m} / \mathrm{s})$ & $V_{P} / V_{S}$ \\
\hline Water & 2356 & 1500 & 0 & - \\
1 & 1049 & 2875 & 1200 & 2.40 \\
2 & 521 & 3505 & 1628 & 2.15 \\
3 & 317 & 4030 & 2190 & 1.84 \\
4 & 109 & 5005 & 2662 & 1.88 \\
5 & 369 & 4220 & 2210 & 1.91 \\
\hline
\end{tabular}

In the Table 2, the carbonate reservoir $\left(V_{P}=3599 \mathrm{~m} / \mathrm{s}\right.$ and $V_{S}=1800 \mathrm{~m} / \mathrm{s}$ ) is under the 7th layer. The 5th, 6th and 7th layers are the salt structure. However, the central layer of the salt structure is not the one which presents the highest values of P-wave and S-wave velocities. For this reason, there is an abnormally low velocity found in the second layer upper than the carbonate reservoir.

Table 2 - The parameters of the Model 2: Layer thickness $(\Delta z)$, P-wave velocity $\left(V_{P}\right)$, S-wave velocity $\left(V_{S}\right)$ and $V_{P} / V_{S}$ ratio.

\begin{tabular}{|c|c|c|c|c|}
\hline Layer & $\Delta z(\mathrm{~m})$ & $V_{P}(\mathrm{~m} / \mathrm{s})$ & $V_{S}(\mathrm{~m} / \mathrm{s})$ & $V_{P} / V_{S}$ \\
\hline Water & 2159 & 1500 & 0 & - \\
1 & 342 & 2879 & 1220 & 2.36 \\
2 & 167 & 3411 & 1599 & 2.13 \\
3 & 294 & 3502 & 1650 & 2.12 \\
4 & 628 & 3680 & 1665 & 2.21 \\
5 & 1071 & 4535 & 2190 & 2.07 \\
6 & 154 & 3912 & 1899 & 2.06 \\
7 & 134 & 4550 & 2210 & 2.06 \\
\hline
\end{tabular}

\section{COMPLEXITY ANALYSIS}

It is important to understand the behavior of each nonhyperbolic approximation concerning the complexity and the unicity. The necessity of determine whether each approximation is unimodal 

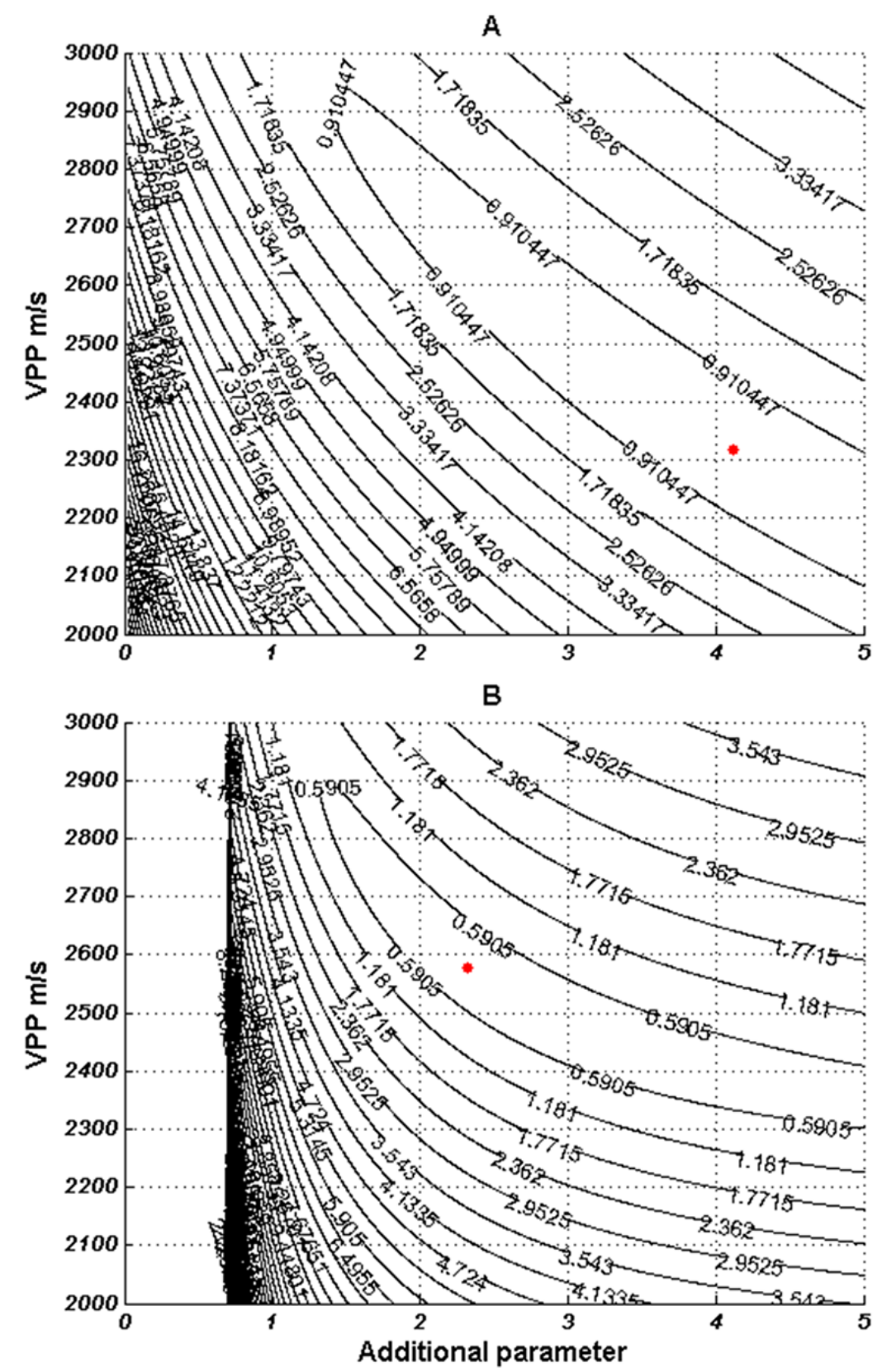

Figure 2 - Residual function maps to demonstrate the complexity of the approximations for the PP event of the Model 1. Red dispersions represent the global minimum regions. (A) Malovichko (1978); (B) Ursin \& Stovas (2006).

or multimodal allows the possibility of select a more compatible approach for each nonhyperbolic expression (Kurt, 2007). The numerical analysis was treated as an inverse problem according an optimization criterion.

For the PP event of the Model 1, the Figures 2 and 3 showed that the approximations proposed by Malovichko (1978), Ursin \& Stovas (2006) and Blias (2009) present only one minimum re- gion each, what relates them with a unimodal behavior. However, the approximation proposed by Li \& Yuan (2001) showed a multimodal behavior, with a global and a local minimum region.

It is possible to observe the same behavior for the PS event of the Model 1 (Figs. 4 and 5) and for the PP (Figs. 6 and 7) and PS (Figs. 8 and 9) events of the Model 2.

The structure of the topography is extremely sensible with the 

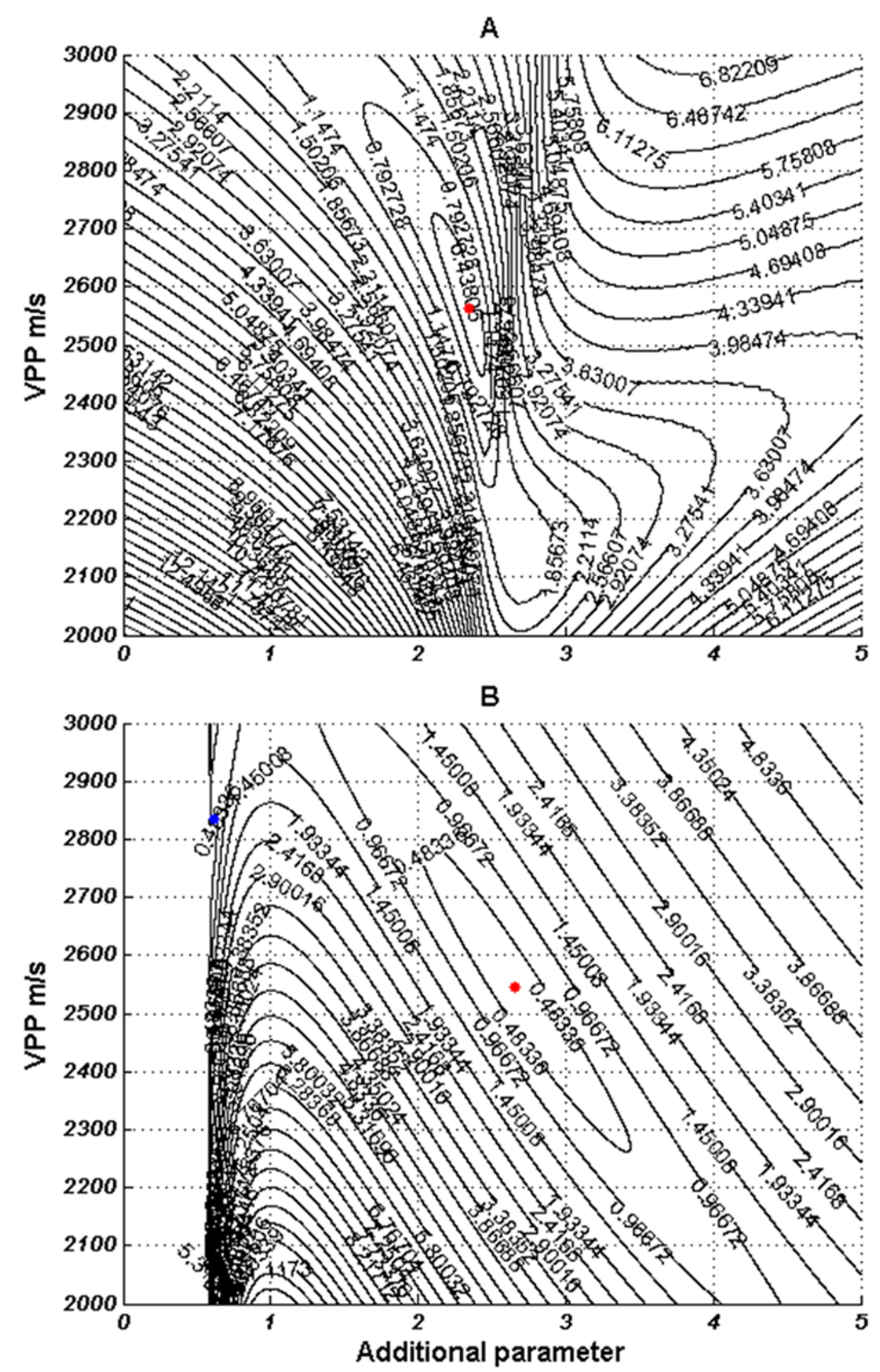

Figure 3 - Residual function maps to demonstrate the complexity of the approximations for the PP event of the Model 1. Red dispersions represent the global minimum regions and the blue dispersions represent the local minimum regions. (A) Blias (2009); (B) Li \& Yuan (2001).

variation of each nonhyperbolic approximation, while the variation of the reflection event is much slighter, with a visible influence concerning the displacement of the structure which is related to the different values of parameters. The topography has a smooth influence with the variation of the model.

\section{COMPARISON OF TRAVEL-TIME APPROXIMATIONS}

The velocity analysis was performed by a comparison among the four nonhyperbolic multiparametric approximations analyz- ing the difference between the observed travel-time curve and the calculated curve with each approximation. Then, the relative errors in travel-time events were computed to analyze the accuracy of each approximation.

For the PP reflection event of the Model 1 (Fig. 10), the approximation proposed by Li \& Yuan (2001) showed the best result and the one which proposed by Blias (2009) showed the second best result. The third and the fourth best results were found respectively by the approximations proposed by 


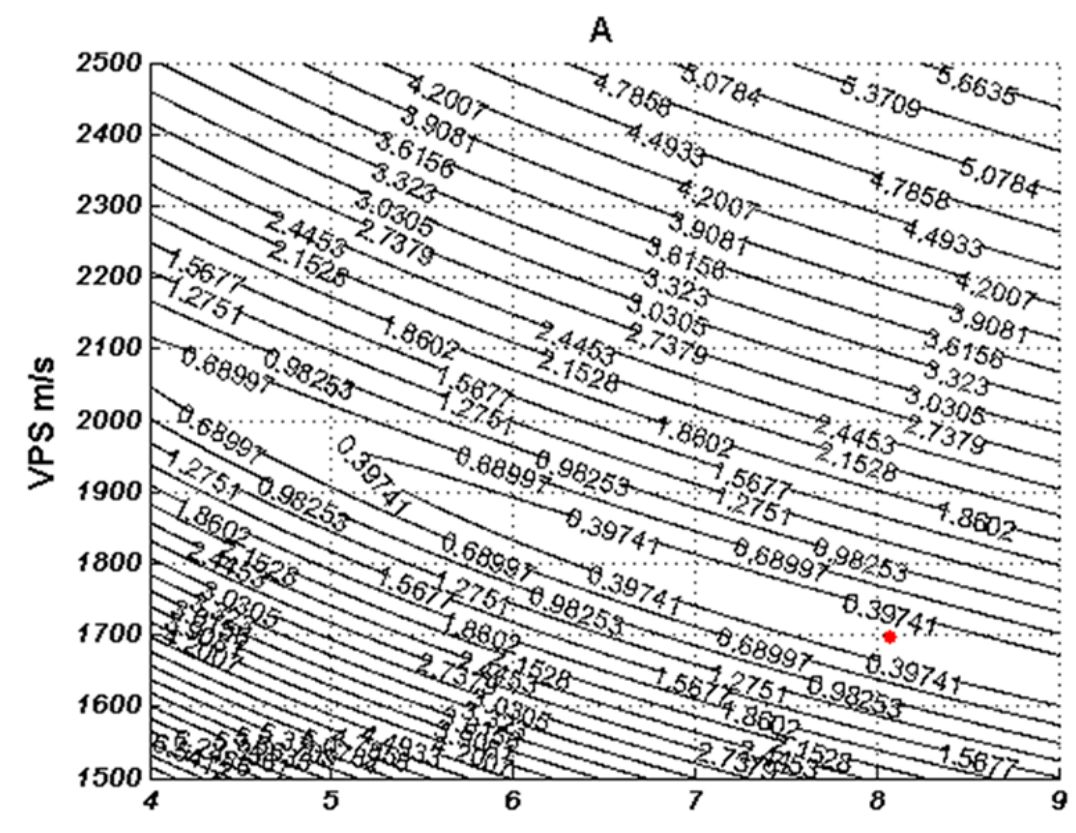

B

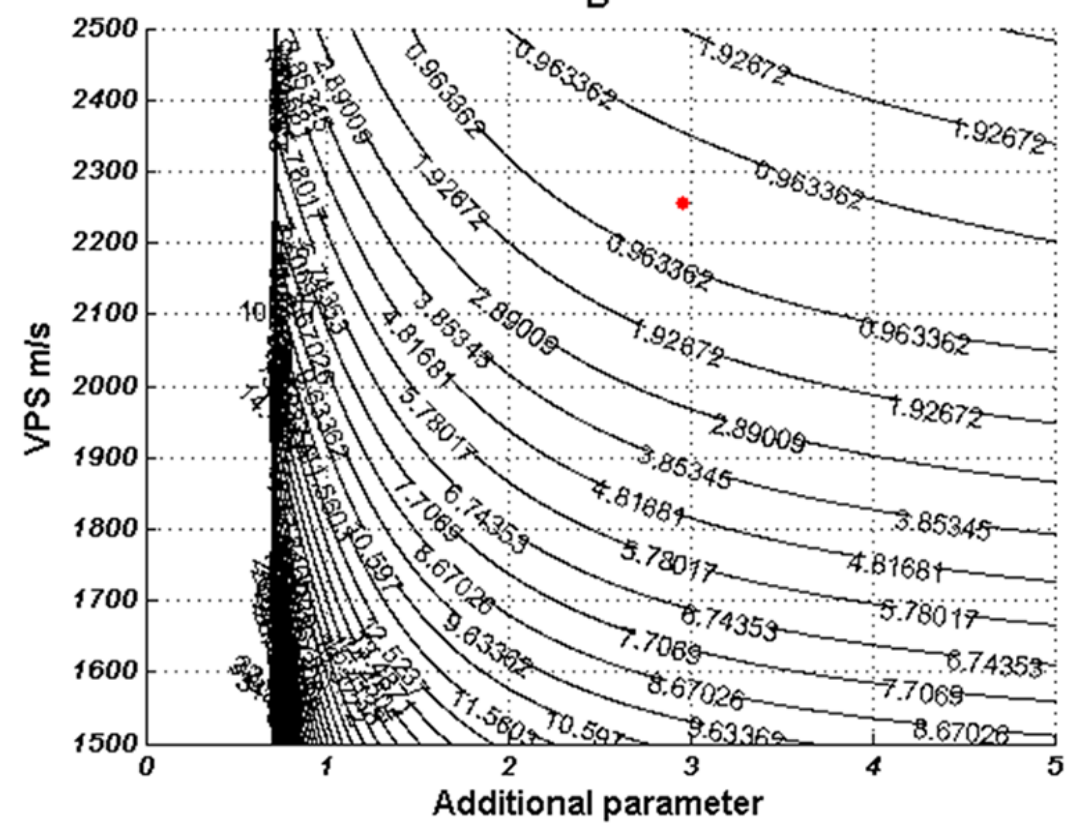

Figure 4 - Residual function maps to demonstrate the complexity of the approximations for the PS event of the Model 1. Red dispersions represent the global minimum regions. (A) Malovichko (1978); (B) Ursin \& Stovas (2006).

Malovichko (1978) and Ursin \& Stovas (2006).

In Figure 11 (converted wave event of the Model 1), the best result can be observed by the approximation proposed by Li \& Yuan (2001), while the second best result shown by Malovichko (1978) approximation. The approximations proposed by Blias (2009) and Ursin \& Stovas (2006) showed the third and the fourth best results respectively.
For the PP event of the Model 2 (Fig. 12) the approximation proposed by Ursin \& Stovas (2006) showed the best result, slightly better than the result shown by the Li \& Yuan (2001) approximation. The approximation proposed by Blias (2009) showed an accuracy almost as good as the other two best results. Even with a good accuracy, the approximation proposed by Malovichko (1978) showed the worst result for this case. 

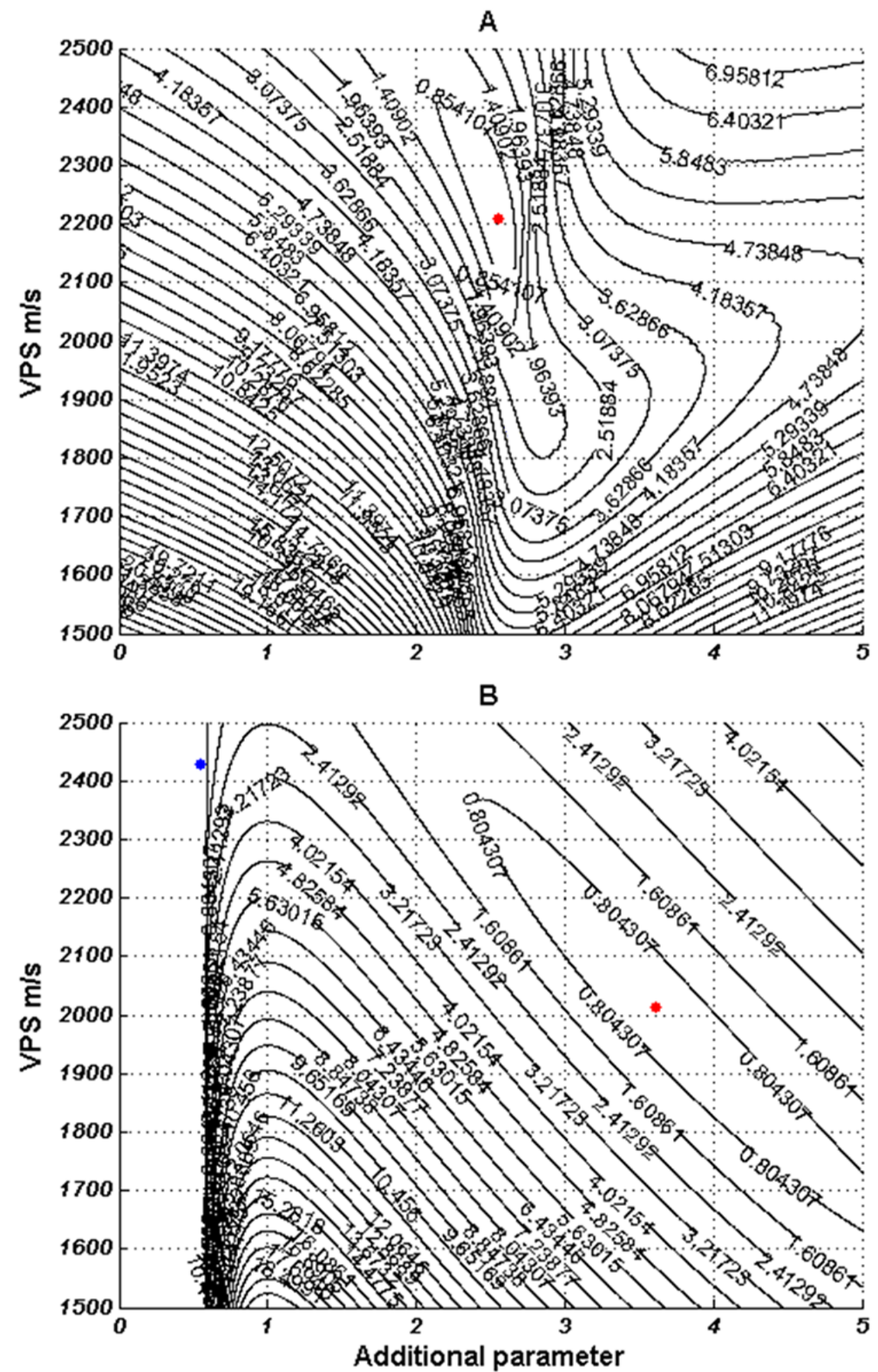

Figure 5 - Residual function maps to demonstrate the complexity of the approximations for the PS event of the Model 1. Red dispersions represent the global minimum regions and the blue dispersions represent the local minimum regions. (A) Blias (2009); (B) Li \& Yuan (2001).

The approximation presented by Li \& Yuan (2001) showed the best results for the converted wave event of the Model 2 (Fig. 13). The approximations proposed by Malovichko (1978), Blias (2009) and Ursin \& Stovas (2006) showed respectively the second best, the third best and the worst result for this reflection event.

Even presenting the best result in the PP event of the Model 2, the approximation proposed by Ursin \& Stovas (2006) 


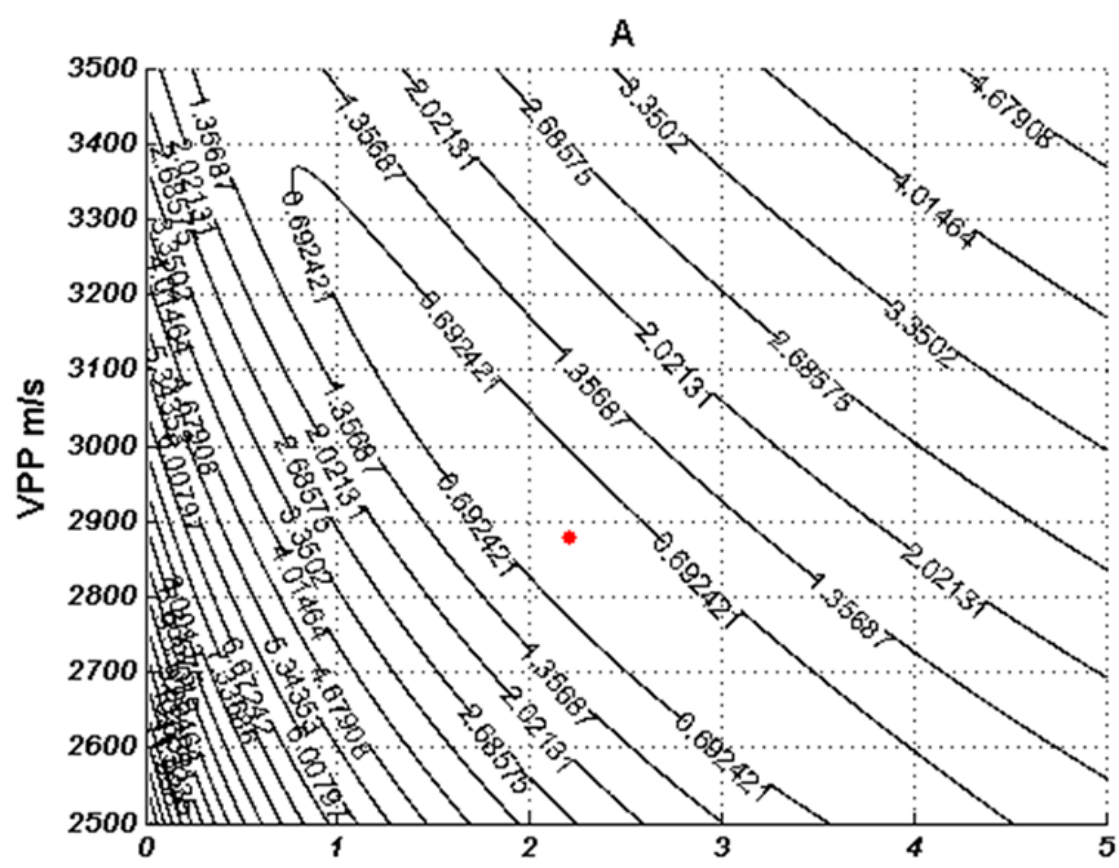

B

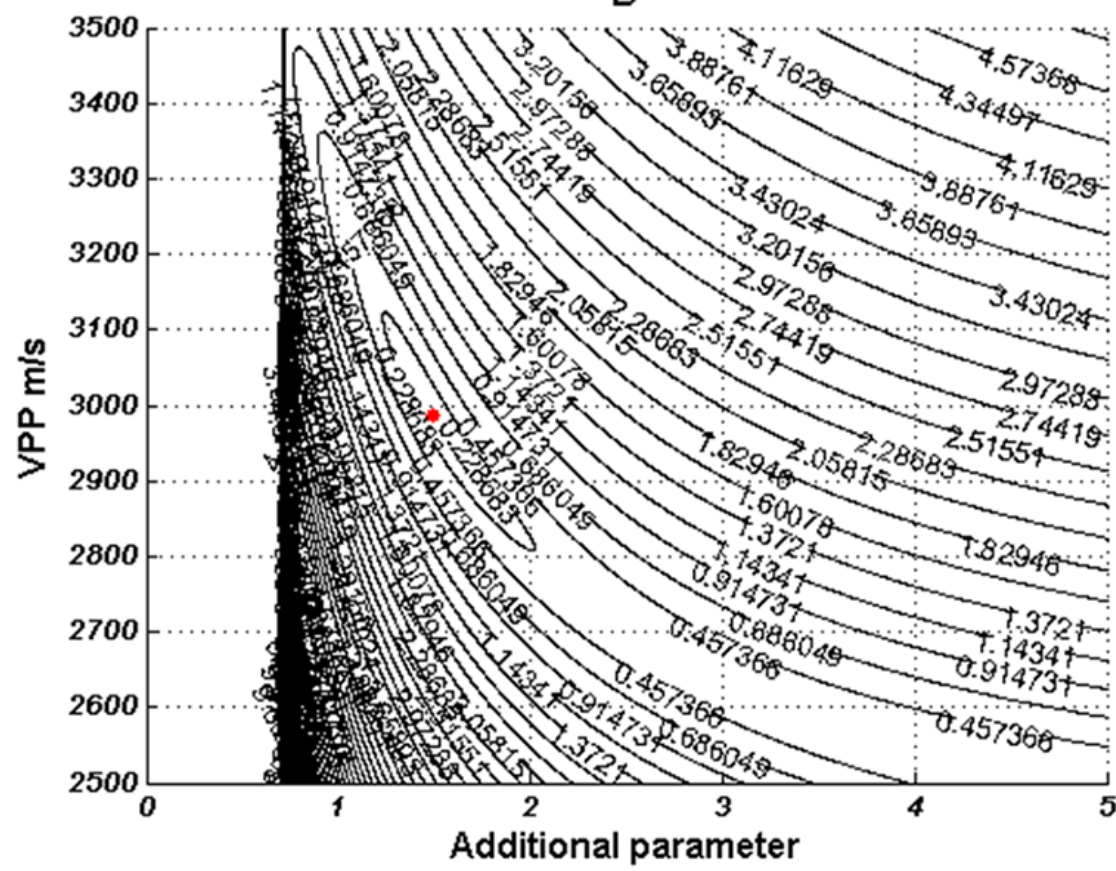

Figure 6 - Residual function maps to demonstrate the complexity of the approximations for the PP event of the Model 2. Red dispersions represent the global minimum regions. (A) Malovichko (1978); (B) Ursin \& Stovas (2006).

showed the worst set of results in a general form. The approximations proposed by Malovichko (1978) and Blias (2009) were shown as the second most accurate approximations for these models. The approximation which showed the best set of results was the one proposed by Li \& Yuan (2001).

\section{CONCLUSIONS}

The behavior shown by the approximations proposed by Ursin \& Stovas (2006) and Blias (2009) are unimodal for all the reflection events tested here. Despite of this, previous works showed that these approximations sometimes have both a multimodal and 


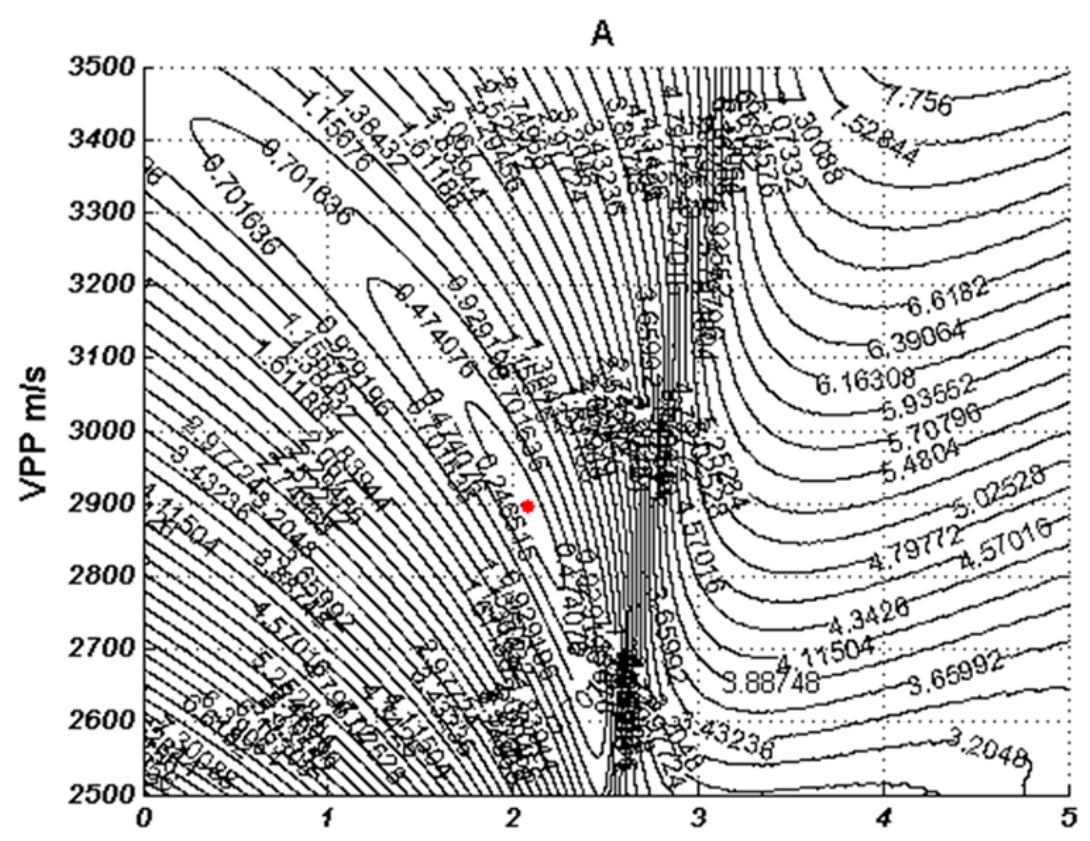

B

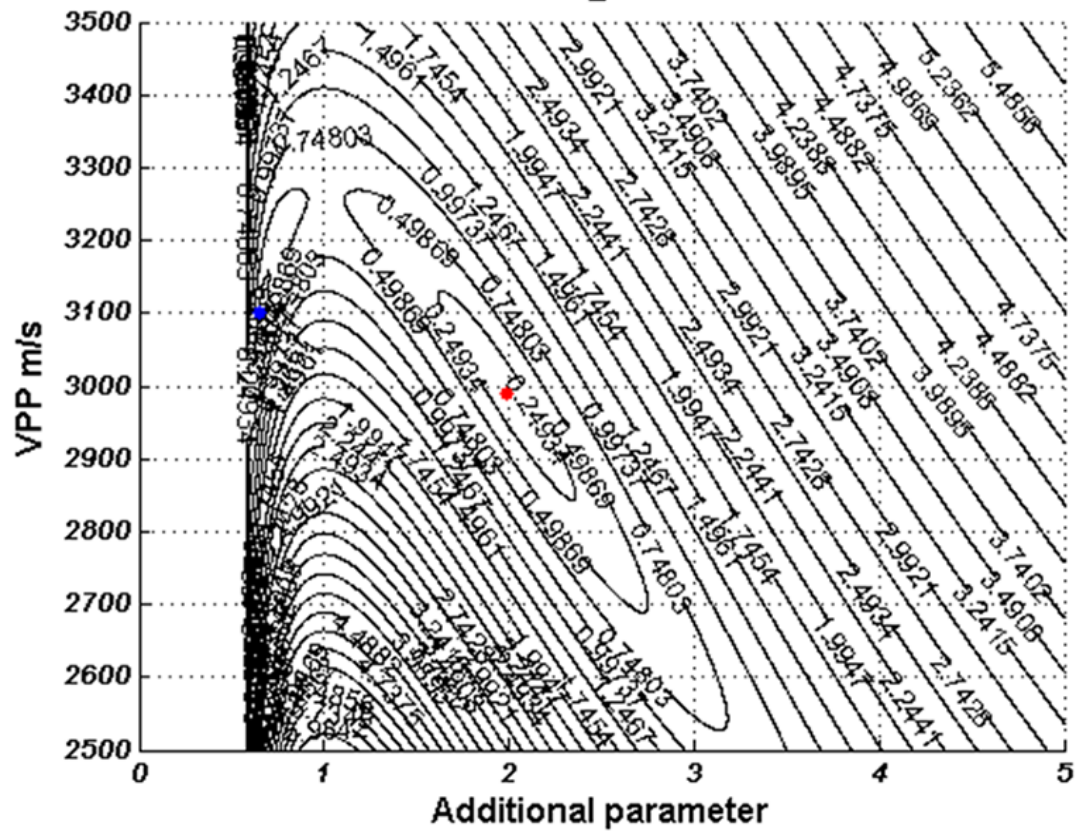

Figure 7 - Residual function maps to demonstrate the complexity of the approximations for the PP event of the Model 2. Red dispersions represent the global minimum regions and the blue dispersions represent the local minimum regions. (A) Blias (2009); (B) Li \& Yuan (2001).

unimodal behaviors (Zuniga et al., 2016; Zuniga, 2017). For this reason, it is difficult to perform a prediction of the behavior of these approximations as it varies with the model. Therefore, even with the good results shown by Blias (2009) approximation, it would take more processing time due to the necessity of a carefully conducted analysis concerning the optimization algorithm to be used.
The approximation proposed by Malovichko (1978) showed an accuracy as good as the Blias approximation. However, it showed to be unimodal for all the tests performed before. For this reason, the approximation proposed by Malovichko (1978) has no necessity to be used with more complex optimization algorithms, what allows the use of local search algorithms to find the global minimum region. 


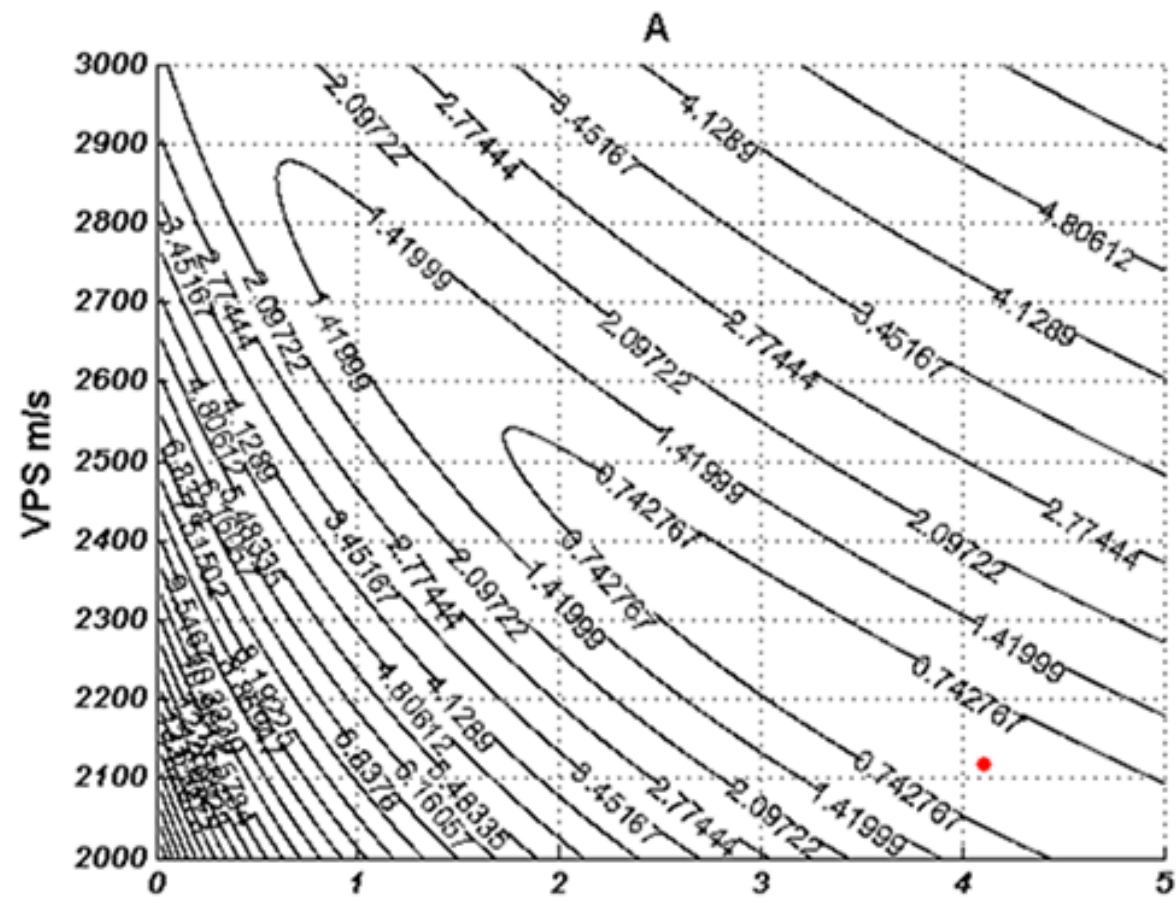

B

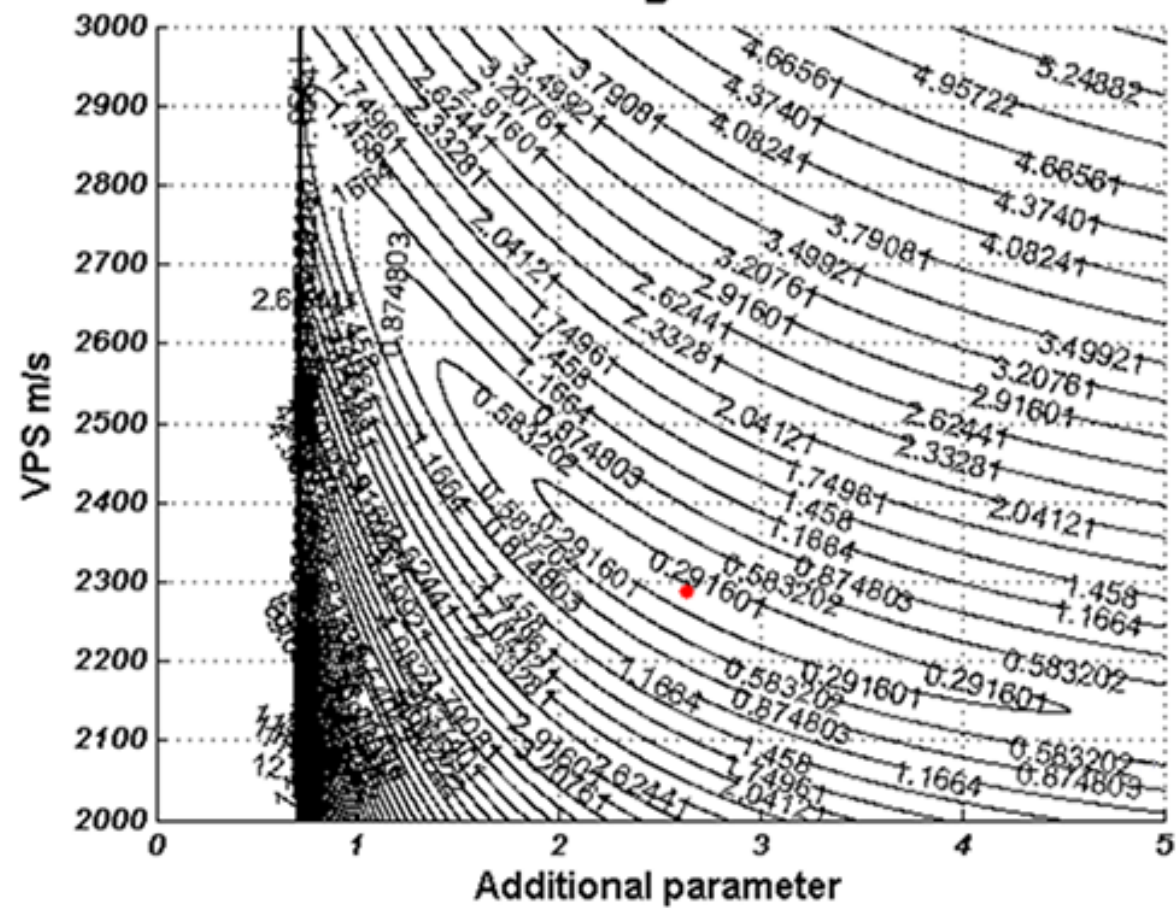

Figure 8 - Residual function maps to demonstrate the complexity of the approximations for the PS event of the Model 2. Red dispersions represent the global minimum regions. (A) Malovichko (1978); (B) Ursin \& Stovas (2006). 


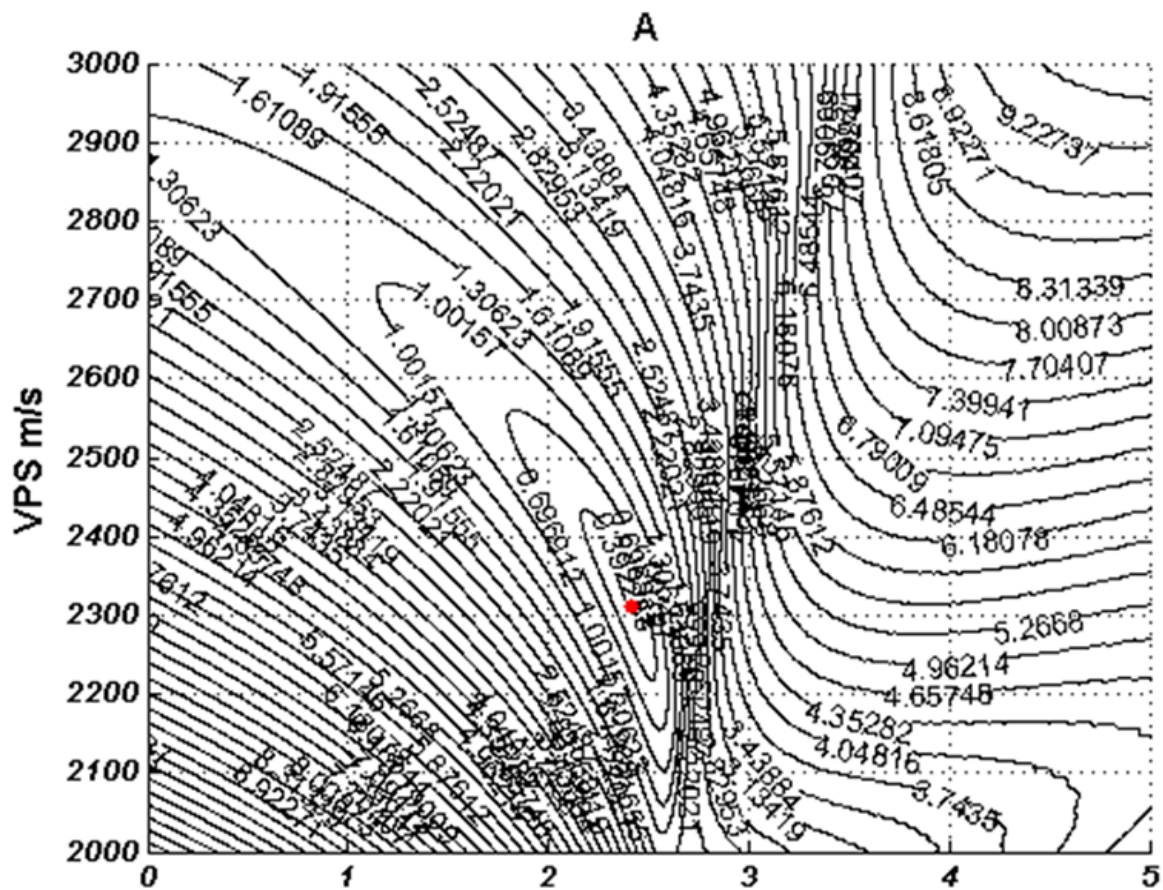

B

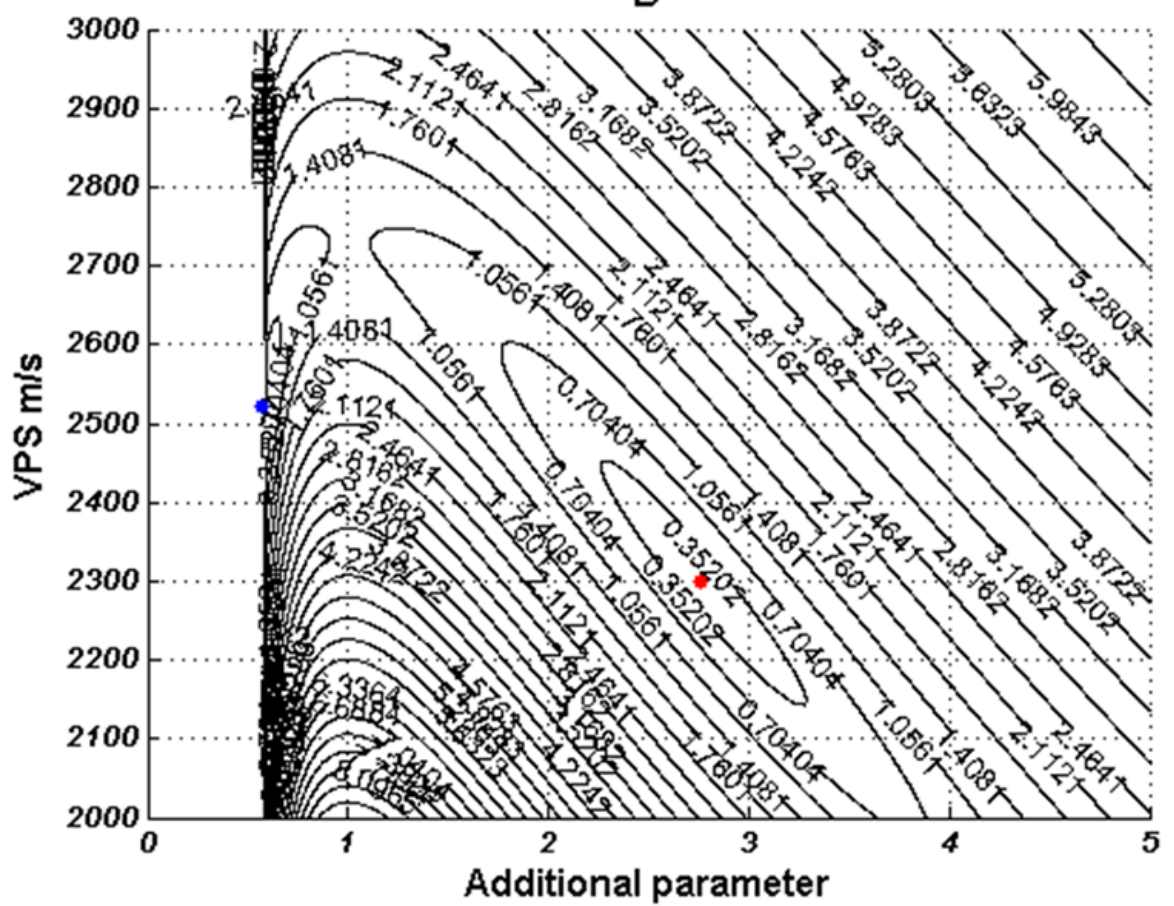

Figure 9 - Residual function maps to demonstrate the complexity of the approximations for the PS event of the Model 2. Red dispersions represent the global minimum regions and the blue dispersions represent the local minimum regions. (A) Blias (2009); (B) Li \& Yuan (2001). 


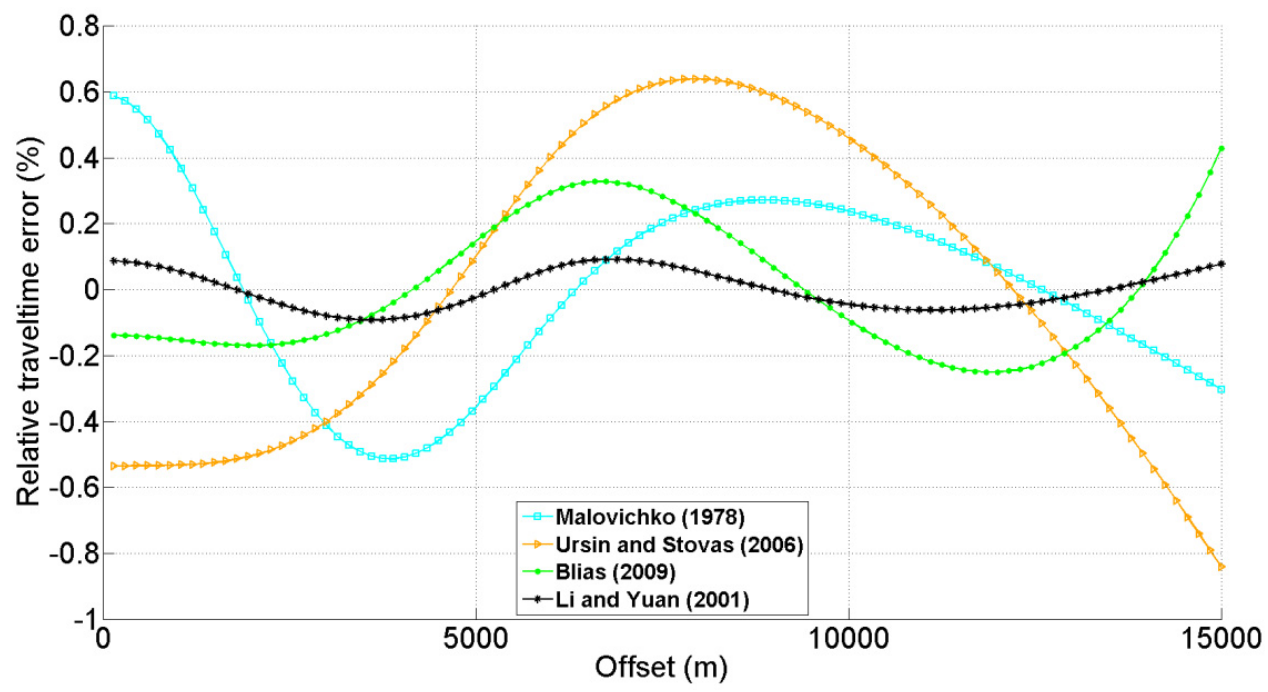

Figure 10 - Relative errors in travel-time between the observed curve and the calculated curve with each approximation, for the PP reflection event of the Model 1.

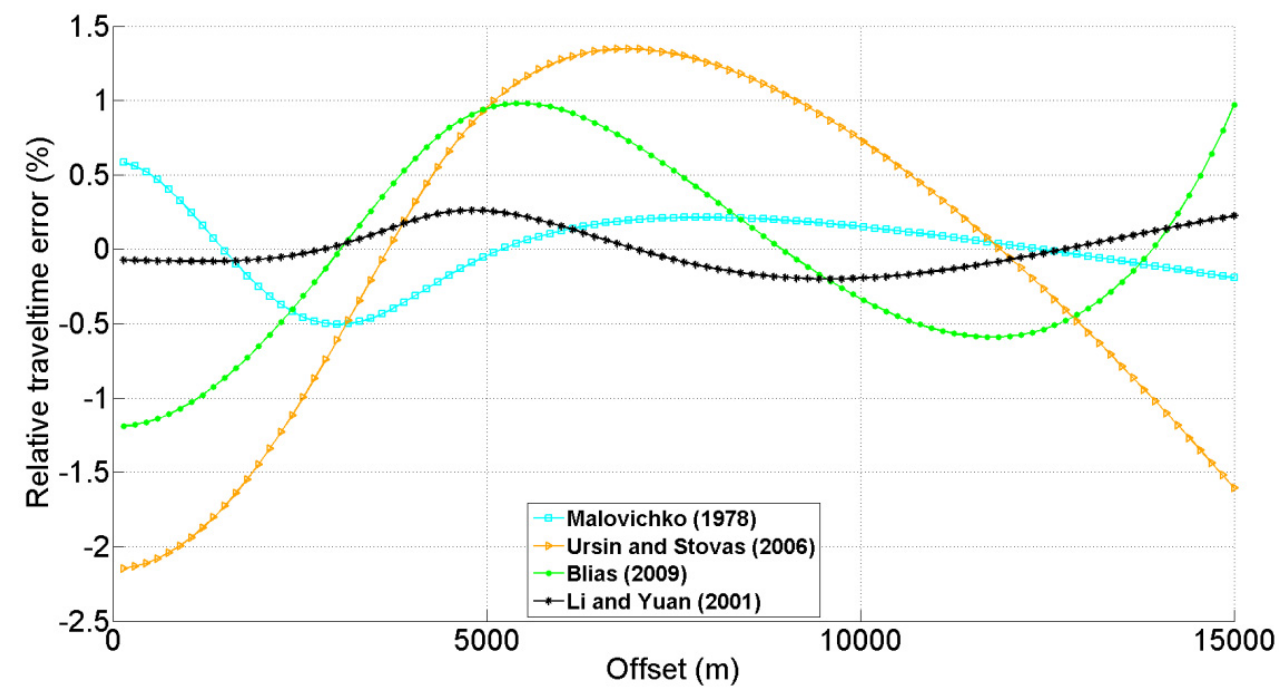

Figure 11 - Relative errors in travel-time between the observed curve and the calculated curve with each approximation, for the PS reflection event of the Model 1.

Li \& Yuan (2001) approximation showed the best set of results for the reflection events analyzed here. However, this approximation is clearly multimodal, what demands the use of a global search optimization algorithm or the application of a multi-start procedure with a local search algorithm.

\section{ACKNOWLEDGEMENTS}

This work was kindly supported by the Brazilian research agency (CAPES - Coordenação de Aperfeiçoamento de Pessoal de Nível Superior).

\section{REFERENCES}

ALEIXO R \& SCHLEICHER J. 2010. Traveltime approximations for q-P waves in vertical transversely isotropic media. Geophysical Prospecting, 58: 191-201.

ALKHALIFAHT \& TSVANKIN I. 1995. Velocity analysis for transversely isotropic Media. Geophysics, 60: 1550-1566.

BLIASE. 1983. Reflected waves travel-time curve in flat-bedded medium with transverse layers and their interpretation. Soviet Geology and Geophysics, N2: 91-95. 


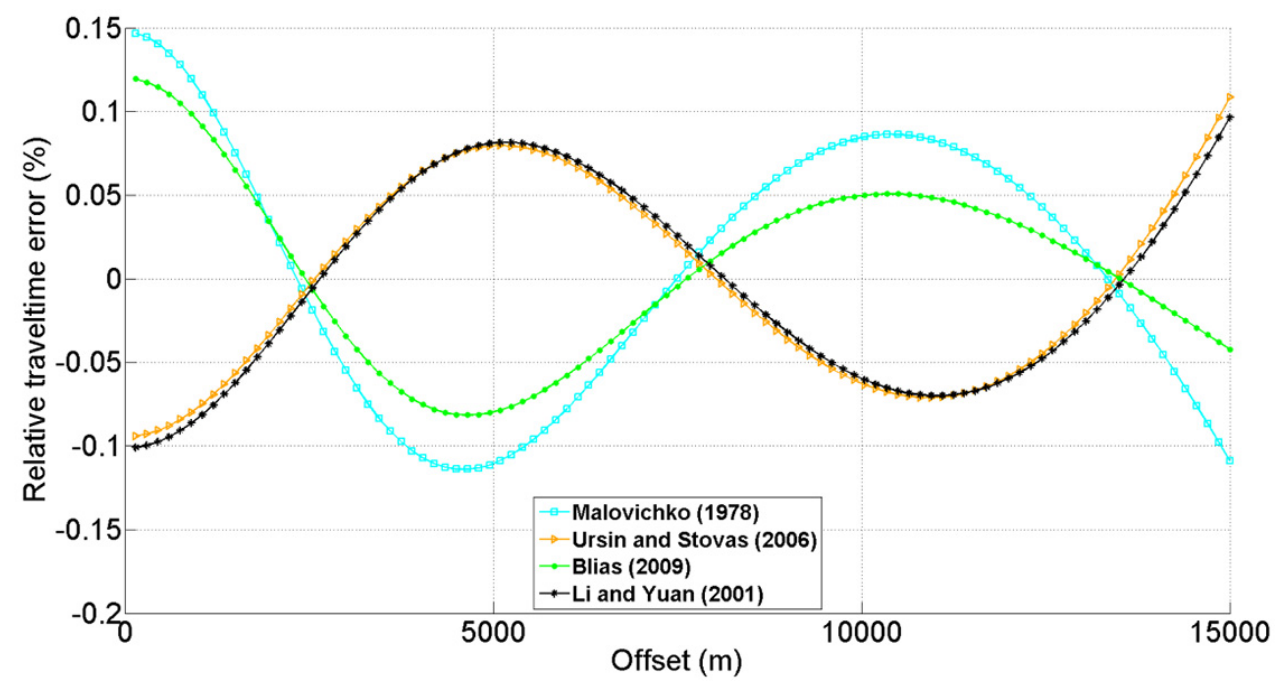

Figure 12 - Relative errors in travel-time between the observed curve and the calculated curve with each approximation, for the PP reflection event of the Model 2.

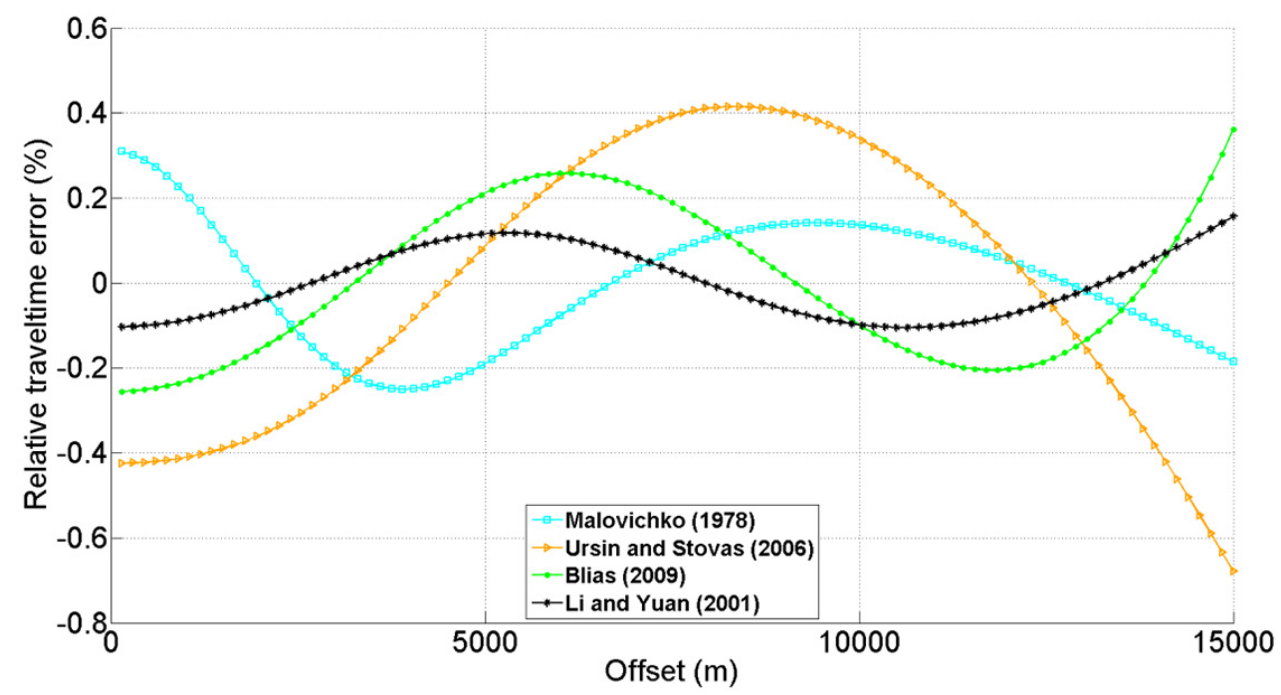

Figure 13 - Relative errors in travel-time between the observed curve and the calculated curve with each approximation, for the PS reflection event of the Model 2.

BLIAS E. 2009. Long-offset NMO approximations for a layered VTI model. Model study. In: 79th Annual International Meeting, Society of Exploration Geophysics, Expanded Abstract, Houston, Texas, USA, p. 3745-3749.

CASTLE RJ. 1988. Shifted hyperbolas and normal moveout. In: 58th Annual International Meeting, Society of Exploration Geophysics, Expanded Abstract, Anaheim, California, USA, p. 894-896.

CASTLE R. 1994. A theory of normal moveout. Geophysics, 59: 983999.

CAUSSE E, HAUGEN GU \& ROMMEL BE. 2000. Large-offset approxi- mation to seismic reflection travel-times. Geophysical Prospecting, 48: 763-778.

CHERET T, BALE R \& LEANEY S. 2000. Parameterization of polar anisotropic moveout for converted waves. In: 70th Annual International Meeting, Society of Exploration Geophysics, Expanded Abstract, Calgary, Alberta, Canada, p. 1181-1184.

DE BAZELAIRE E. 1988. Normal moveout revisited: Inhomogeneous media and curved interfaces. Geophysics, 53: 143-157.

DIX CH. 1955. Seismic velocities from surface measurements. Geophysics, 20: 68-86. 
FOMEL S \& GRECHKA V. 2000. Nonhyperbolic reflection moveout in anisotropic media. Stanford Exploration Project, p. 617-640.

FOMEL S \& GRECHKA V. 2001. Nonhyperbolic reflection moveout of P-waves: An overview and comparison of reasons. Center for Wave Phenomena, CWP-372. Colorado School of Mines, Colorado, USA, $23 \mathrm{pp}$.

GOLIKOV P \& STOVAS A. 2012. Accuracy comparison of nonhyperbolic moveout approximations for qP-waves in VTI media. Journal of Geophysics and Engineering, 9: 428-432.

KURT H. 2007. Joint inversion of AVA data for elastic parameters by bootstrapping. Computers \& Geosciences, 33(3): 367-382.

LI XY. 2003. Converted-wave moveout analysis revisited: The search for a standard approach. In: 73rd Annual International Meeting, Society of Exploration Geophysics, Expanded Abstract, Dallas, Texas, USA, p. 805-808.

LI XY \& YUAN J. 1999. Converted-wave moveout and parameter estimation for transverse isotropy. In: 61st EAGE Conference, Expanded Abstract, 1: 4-35.

LI XY \& YUAN J. 2001. Converted-wave imaging in inhomogeneous, anisotropic media: Part I - Parameter estimation. In: 63rd EAGE Conference, Expanded Abstract, Amsterdam, The Netherlands, 1: 4 pp.

MALOVICHKO AA. 1978. A new representation of the travel-time curve of reflected waves in horizontally layered media. Applied Geophysics (in Russian), 91(1): 47-53.

MUIR F \& DELLINGER J. 1985. A practical anisotropic system. In: SEP44. Stanford Exploration Project, p. 55-58.

SLOTB00M RT. 1990. Converted wave (P-SV) moveout estimation. In: 60th Annual International Meeting, Society of Exploration Geophysics, Expanded Abstract, San Francisco, California, USA, p. 1104-1106.
THOMSEN L. 1986. Weak elastic anisotropy. Geophysics, 51: 19541966.

TSVANKIN I \& GRECHKA V. 2000a. Dip moveout of converted waves and parameter estimation in transversely isotropic media. Geophysics, 48: 257-292

TSVANKIN I \& GRECHKA V. 2000b. Two approaches to anisotropic velocity analysis of converted waves. In: 70th Annual International Meeting, Society of Exploration Geophysics, Expanded Abstract, Calgary, Alberta, Canada, p. 1193-1196.

TSVANKIN I \& THOMSEN L. 1994. Nonhyperbolic reflection moveout in anisotropic media. Geophysics, 59: 1290-1304.

URSIN B \& STOVAS A. 2006. Traveltime approximations for a layered transversely isotropic medium. Geophysics, 71: 23-33.

YILMAZ 0. 2000. Seismic Data Analysis. Society of Exploration Geophysics, Tulsa, $2027 \mathrm{pp}$.

ZUNIGA NRCF. 2017. Análise comparativa de aproximações não-hiperbólicas dos tempos de trânsito de dados sísmicos multicomponente utilizando tecnologia OBN. Master's Thesis, Universidade de São Paulo, São Paulo, Brazil, 86 pp.

ZUNIGA NRCF, BOKHONOK 0 \& DIOGO LA. 2015. Comparison of nonhyperbolic travel-time approximations for multicomponent seismic data. In: 14th International Congress of the Brazilian Geophysical Society \& EXPOGEF, Expanded Abstract, Rio de Janeiro, Brazil, 1176.

ZUNIGA NRCF, MOLINA EC \& PRADO RL. 2016. Inversion of multicomponent seismic data for VTI medium using the globalized Nelder-Mead optimization algorithm. In: 3th EAGE/SBGf Workshop, Expanded Abstract. Rio de Janeiro, Brazil. 